\title{
PORT EVERGLADES SAND BYPASSING: AN IMPORTANT FUTURE SAND SOURCE FOR SOUTH FLORIDA
}

\author{
Christopher G. Creed, P.E., D.CE, OIsen Associates, Inc., ccreed@olsen-associates.com \\ Nicole S. Sharp, P.E., Broward County, Florida, nsharp@broward.org \\ Steven C. Howard, P.E., D.CE, Olsen Associates, Inc., showard@olsen-associates.com
}

This paper will describe the history, planning, design, and construction of a new sand bypass project at Port Everglades Inlet in Broward County, Florida, USA. The sand bypass project will address one of the most significant remaining inlet sand management needs in Florida. The discussion will focus on the importance of the sand bypass project to the future sustainability of beaches in South Florida where beach nourishment sand from traditional sources has been depleted. The paper will also highlight the highly complex physical, environmental, and socio-political conditions that have guided the planning and implementation of the project.

\section{BACKGROUND}

Port Everglades (PE) Inlet, located in Broward County, Florida, is a complete barrier to littoral drift. The inlet hosts a Federal navigation channel that is maintained to a depth of more than 15 meters. There are no ebb or flood tidal shoals to support natural sand transport across the inlet. Most sand transported to the inlet is from the north, which either impounds along the north beach, deposits in the deep inlet channel, or moves permanently offshore. As a result, there is no natural input of sand to the beach downdrift (south) of the inlet.

Since inlet construction in 1928, the downdrift beach has been highly erosional, and efforts to compensate for the absence of the natural sand supply have been limited to beach nourishment using nearby offshore sand resources. These traditional cost-effective sand sources, however, have been exhausted by dozens of projects constructed throughout the County since 1970. Currently, the only known sand source for future beach nourishment projects in Broward County is from upland sand mines. The long-term sustainability of these sources is unclear.

\section{PROJECT PURPOSE AND NEED}

Sand bypassing at PE Inlet will provide a reliable sand source for the downdrift beaches. The project is predicted to make available a sand volume equivalent to roughly 50 percent of the average annual need along the $13 \mathrm{~km}$ beach south of the inlet. The project will also reduce sand shoaling in $\mathrm{PE}$ Inlet and the Federal navigation channel.

Sand bypassing at PE Inlet has been evaluated extensively since the 1960's, but project implementation has been complicated by many economic, physical, and political constraints. Given the decreased availability of offshore sand, sand bypassing has become economically feasible as a future beach nourishment sand source.

\section{PROJECT SCOPE}

The PE Inlet Sand Bypass Project will utilize a "sand storage" approach. The project will include the construction of a sand trap on the north side of the inlet channel. The project also will improve the inlet's north jetty and remove a large relict rubble spoil shoal north of the sand trap. Removal of the spoil shoal will facilitate sand transport to the trap and re-expose 2.96 hectares of hardbottom reef that will serve as mitigation. The project's sand trap will be dredged into the rock seabed and will be separated from the adjacent Federal channel by a narrow rock sill that will maintain the existing channel wall. This is particularly important to maintain existing, uniform hydraulic bank effects along the channel wall for large ship navigation. The sand trap will be dredged every two to four years and the sand will be transported across the inlet for placement along the downdrift beach.

\section{CONSTRUCTION}

The construction and operation of the project is complicated by the location of the sand trap relative to the Federal navigation channel, local geology, and adjacent hardbottom resources that support Federally-listed threatened and endangered corals. Permits for the project have been secured and construction is anticipated to be complete by summer 2019 .

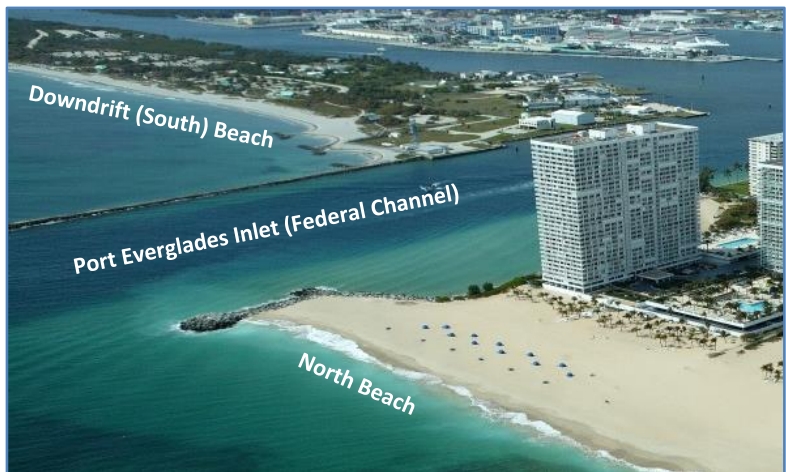

Figure 1 - Port Everglades Inlet and adjacent beaches.

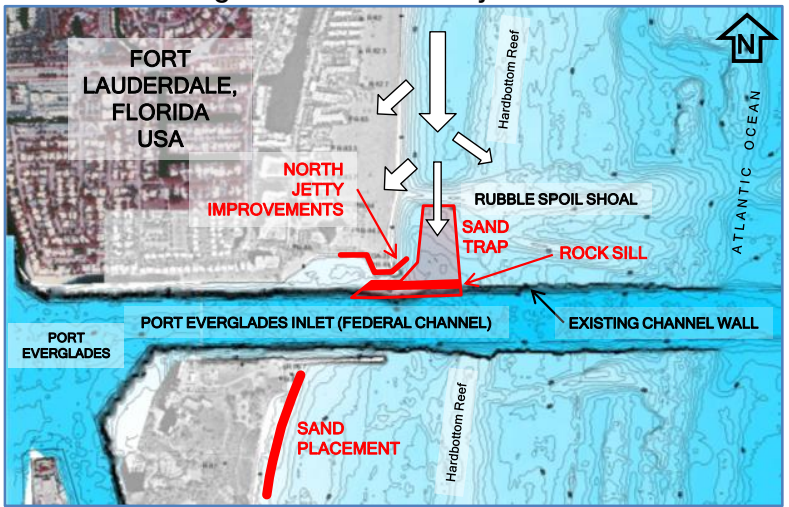

Figure 2 - Port Everglades Inlet sand bypass plan. 